\title{
Chitosan and D-Glucosamine Induce Expression of Th1 Cytokine Genes in Porcine Spleen Cells
}

\author{
Deog-Yong $\mathrm{LEE}^{1)}$, In-Soo CHOI ${ }^{1)}$, Jeong-Hee $\mathrm{HAN}^{2)}$ and Han-Sang $\mathrm{YOO}^{1) *}$ \\ ${ }^{1)}$ Department of Infectious Diseases, College of Veterinary Medicine and School of Agricultural Biotechnology, Seoul National University, \\ Suwon 441-744 and ${ }^{2)}$ Department of Veterinary Medicine, Kangwon National University, Chuncheon, 200-701 Korea
}

(Received 1 March 2002/Accepted 20 March 2002)

ABSTRACT. Chitosan, a polymer of D-glucosamine, is a polysaccharide derived from the chitin found in the exoskeleton of shellfish, such as shrimp or crabs. The effects of chitosan has been recognized that chitosan-fed farm animals demonstrated higher weight gains but less incidence of diseases than the unfed ones. However, these beneficial effects has not been elucidated clearly. In this study, we examined the modulatory effect of chitosan and D-glucosamine on the expression of porcine cytokines in vitro. Porcine spleen cells were cultured in the presence of chitosan and D-glucosamine, and the effects of chitosan on the cytokine mRNA expression were evaluated. Expressions of IL- 2 and IFN- $\gamma$ were increased in the chitosan-treated porcine spleen cells. Expressed cytokines in the D-glucosaminetreated cells were IL-2, IFN- $\gamma$, and IL-12 p40 subunit. In particular, IFN- $\gamma$ was expressed more efficiently, and D-glucosamine was more effective for expressing the cytokine gene. These results suggest chitosan as well as D-glucosamine could induce the expression of cytokines as Th1 subset such as IL-2, IFN- $\gamma$.

KEY WORDS: chitosan, D-glucosamine, porcine cytokine expression.

T lymphocytes, which secrete different cytokines, are divided into two subsets, designated as Th1 and Th2 (16). Th1 subset cells are responsible for cell-mediated immune functions and the production of opsonization-promoting IgG antibodies [16]. They secrete cytokines such as interleukin-2, interferon- $\gamma$, tumor necrosis factor- $\beta$ and granulocyte and macrophage colony-stimulating factors. On the other hand, Th2 subset cells, which secrete cytokines such as interleukin-4, interleukin-5 and interleukin-10, are responsible for inducing humoral immunity, including the activation and differentiation of eosinophils, and providing help to B cells. Th1 and Th2 cytokines have mutual inhibitory relations in regulating immune responses. In addition to the cross-regulation of the Th1 and Th2 subsets, progression of a number of diseases depends on the balance between the Th1 and Th2 cytokines [16].

Chitosan, a polymer of D-glucosamine, is a natural product derived from chitin, a polysaccharide found in the exoskeleton of shellfish such as shrimps and crabs, and is chemically similar to plant fibers. The antimicrobial activity of chitosan was well-observed on a wide variety of microorganisms including fungi, algae, and some bacteria [3], and generally accepted to increase the weights gain of economic farmed animals. Chitin and its derivates have also been reported to have a cancer therapeutic effect on the Meth-A tumor in BALB/C mice [5, 13]. DNA fragmentation, which is a characteristic of apoptosis, and elevated caspase-3-like activity were observed in chitosan-treated cancer cells [5]. Moreover, chitosan was also reported to have adjuvant activity in a vaccine [15], and its microparti-

\footnotetext{
* Correspondence to: Yoo, H.-S., Department of Infectious Diseases, College of Veterinary Medicine and School of Agricultural Biotechnology, Seoul National University, Suwon 441-744, Korea.
}

cles suitable for oral vaccination using ovalbumin as a model vaccine [20]. In addition, co-administration of chitosan and its derivates was considered to improve the bioavailability of many perorally administered peptide drugs for mucoadhesive property [1]. Chitosan is also known to stimulate the secretion of cytokines and induce cytotoxic macrophage [13, 14, 22]. Although it is generally recognized that chitosan-fed animals exhibit an improved health state, how the chitosan-treatment exerts the beneficial effect in animal has not been defined. Therefore, the modulatory effect of chitosan and D-glucosamine on the expression of porcine cytokines, including IFN- $\gamma$, IL-2, IL-4, IL-5, IL-6, IL-10 and IL-12 in vitro was examined in this study.

Spleen cells were obtained from 2-3 months old conventional pigs. Eight pigs were used in this study. The spleen cells were prepared from a piece of spleen by grinding it on metal mesh in complete RPMI 1640 medium. They were treated with $\mathrm{RBC}$ lysis buffer $\left(0.145 \mathrm{M} \mathrm{NH}_{4} \mathrm{Cl}, 0.017 \mathrm{M}\right.$ Tris ( $\mathrm{pH} 7.65), \mathrm{pH}$ 7.2) for $2 \mathrm{~min}$ at room temperature. And then, the cells were underlayed with FBS and centrifuged at $300 \times \mathrm{g}$ for $10 \mathrm{~min}$. They were washed twice with the complete RPMI 1640 medium. They were counted by the trypan-blue exclusion method and then seeded in $25-\mathrm{cm}^{2}$ tissue culture flasks at about $5.0 \times 10^{6}$ cells $/ \mathrm{m} l[10]$.

Chitosan was provided by Bio-Resourse Inc. (Seoul, Korea). The spleen cells were divided into three groups. The first group cells were used as untreated control cells. The second and third groups cells were treated with 0.001 and 0.005-diluted chitosan, respectively. D-glucosamine (Sigma Co., St. Louis, MO, U.S.A.) was used to stimulate the spleen cells. The spleen cells were also divided into three groups. The first group cells were used as the untreated control cells. The second and third group cells were treated with 5 and $50 \mu \mathrm{g} / \mathrm{m} l$ diluted D-glucosamine, 
respectively. All cells were then incubated for $24 \mathrm{hr}$ at $37^{\circ} \mathrm{C}$ in $5 \% \mathrm{CO}_{2}$.

The stimulated spleen cells were harvested for total RNA extraction. Total RNA was isolated from the control and the experimental cells treated with chitosan and D-glucosamine using Trizol Reagent (Gibco, Gaitherburg, MD, U.S.A.). The RNA pellets was washed once with $75 \%$ ethanol and dissolved in DEPC-treated water. The RNA was treated with 2 units of RNase-free DNase for $30 \mathrm{~min}$ at $37^{\circ} \mathrm{C}$ to remove the residual DNA, and was purified again with Trizol Reagent.

High concentration of chitosan aggregated the total mRNA pellet and produced a yellowish pellet, which was insoluble in sterilized water. This aggregation was changed into soluble state in sterilized water through incubating at $60^{\circ} \mathrm{C}$ for $10 \mathrm{~min}$. Single-stranded cDNA was made using the Superscript Preamplication System for First Strand cDNA Synthesis Kit (Gibco, Gaitherburg, MD, U.S.A.). Briefly, $5 \mu \mathrm{g}$ of RNA was incubated for $50 \mathrm{~min}$ at $42^{\circ} \mathrm{C}$ in the presence of $10 \times \mathrm{RT}$ buffer, $25 \mathrm{mM} \mathrm{MgCl} 2,10 \mathrm{mM}$ dNTP, 0.1 M DTT, and 50 units of Superscript II RT. Samples were treated with 2 units of RNaseH for $20 \mathrm{~min}$ at $37^{\circ} \mathrm{C}$, and synthesized single-stranded cDNA was used as a template in the PCR. Each cytokine gene expression was examined through PCR amplication (45 cycles) with its respective cytokine-specific primer set (Table 1) and a template cDNA under the following conditions: IL-2; $94^{\circ} \mathrm{C}$ for $30 \mathrm{~s}, 53^{\circ} \mathrm{C}$ for $30 \mathrm{~s}$, and $72^{\circ} \mathrm{C}$ for $45 \mathrm{~s}$ : IL- $4 ; 94^{\circ} \mathrm{C}$ for $30 \mathrm{~s}$, $55^{\circ} \mathrm{C}$ for $30 \mathrm{~s}$, and $72^{\circ} \mathrm{C}$ for 45 : IL-5; $94^{\circ} \mathrm{C}$ for $30 \mathrm{~s}, 48^{\circ} \mathrm{C}$ for $30 \mathrm{~s}$, and $72^{\circ} \mathrm{C} 30 \mathrm{~s}$ : IL- $6 ; 94^{\circ} \mathrm{C}$ for $30 \mathrm{~s}, 53^{\circ} \mathrm{C}$ for $30 \mathrm{~s}$, and $72^{\circ} \mathrm{C}$ for $45 \mathrm{~s}$ : IL- $10 ; 94^{\circ} \mathrm{C}$ for $30 \mathrm{~s}, 52^{\circ} \mathrm{C}$ for $30 \mathrm{~s}$, and $72^{\circ} \mathrm{C}$ for $45 \mathrm{~s}$ : IL- $12 \mathrm{p} 35 ; 94^{\circ} \mathrm{C}$ for $30 \mathrm{~s}, 50^{\circ} \mathrm{C}$ for $30 \mathrm{~s}$, and $72^{\circ} \mathrm{C}$ for $45 \mathrm{~s}$ : IL- $12 \mathrm{p} 40 ; 94^{\circ} \mathrm{C}$ for $30 \mathrm{~s}, 58^{\circ} \mathrm{C}$ for $30 \mathrm{~s}$, and $72^{\circ} \mathrm{C}$ for $60 \mathrm{~s}$ : IFN- $\gamma ; 94^{\circ} \mathrm{C}$ for $30 \mathrm{~s}, 50^{\circ} \mathrm{C}$ for $30 \mathrm{~s}$, and $72^{\circ} \mathrm{C}$ for $45 \mathrm{~s}$. Cyclophilin A was used as a control housekeeping gene to compare the cytokine gene expression, and its expression was demonstrated through PCR amplication (40 cycles) under the following conditions: $94^{\circ} \mathrm{C}$ for $30 \mathrm{~s}, 55^{\circ} \mathrm{C}$ for $30 \mathrm{~s}$, and $72{ }^{\circ} \mathrm{C}$ for $30 \mathrm{~s} \mathrm{[21].}$

All PCR products were electrophoresized in $1.5 \%$ agarose gel and examined under UV light after ethidium bromide staining. Densities of the expressed cytokine genes bands were divided by that of the control housekeeping gene, cyclophilin A in order to normalize the expression levels of cytokine gene.

Specificity of PCR reactions for the detection of expressed cytokines and cyclophilin A genes with each gene-specific primer set and cDNA made from mRNA of PHA-stimulated porcine PBMC under each gene-specific condition (Fig. 1). This result indicated that the PCR conditions used in this study were suitable for the detection of expressed cytokine mRNA in the porcine spleen cells. Also, the expression levels of cyclophilin A as a house-keeping gene were consistent in the control, and the chitosan- or Dglucosamine-treated cells (data not shown).

Optimal stimulating time was determined by analyzing the gene expression at different time intervals. After stimulating for 2, 4, 24, 48, and $72 \mathrm{hr}$, the optimal expression of cytokine was observed firstly and the most clearly at $24 \mathrm{hr}$ after stimulation. Therefore, incubation time of spleen cells with stimulation was $24 \mathrm{hr}$ in other experiments.

Expressed cytokines in the D-glucosamine-treated cells were IL- 2 , IFN- $\gamma$, and IL-12 p40 subunit. Increased expression levels of IL-2, IFN- $\gamma$, and IL-12 p40 subunit were evident in cells stimulated with $50 \mu \mathrm{g} / \mathrm{m} l \mathrm{D}$-glucosamine (Fig. 2). Although expressions of IL- 2 and IFN- $\gamma$ were not increased in cells treated with $5 \mu \mathrm{g} / \mathrm{m} l \mathrm{D}$-glucosamine, they were sharply elevated in $50 \mu \mathrm{g} / \mathrm{m} l \mathrm{D}$-glucosamine-treated cells. In contrast, IL-12 p40 subunit expression was continually increased in D-glucosamine-treated cells in a dosedependent manner. Other cytokines, including IL-4, IL-5, IL-6, IL-10, and IL-12 p35 subunit were not expressed in

Table 1. Oligonucleotide sequences of the primers used in this study

\begin{tabular}{|c|c|c|}
\hline Primer & Oligonucleotide sequences & Sizes of amplified products \\
\hline \multirow[t]{2}{*}{ IL-2 } & 5'-ATGTATAAGATGCAGCTCTTG -3' & $465 \mathrm{bp}$ \\
\hline & 5'- TCAAGTCAGTGTTGAGTAGATG -3' & \\
\hline \multirow[t]{2}{*}{ IL-4 } & 5’- ATGGGTCTCACCTCCCAACTG -3' & 402 bp \\
\hline & 5'- TCAACACTTTGAGTATTTCTCCTTC -3' & \\
\hline \multirow[t]{2}{*}{ IL-5 } & 5'-ATGAGAATGCTTCTGCATTTG -3' & $405 \mathrm{bp}$ \\
\hline & 5'- TTAАCTTTCСАTТGTCCACTC -3' & \\
\hline \multirow[t]{2}{*}{ IL-6 } & 5'- ATGAACTCССТCTCCACAAGC -3' & $639 \mathrm{bp}$ \\
\hline & 5'- CTACATTATCCGAATGGCCCTC -3' & \\
\hline \multirow[t]{2}{*}{ IL-10 } & 5’- ATGCCCAGCTCAGCACTGC -3' & $528 \mathrm{bp}$ \\
\hline & 5'- TCAGTTCTTCCTCATCTTCATC -3' & \\
\hline \multirow[t]{2}{*}{ IL-12 p35 } & 5'- ATGTGTCCGCTGCGCAAC -3' & $669 \mathrm{bp}$ \\
\hline & 5'- TTAGGAAGAATTCAGATAGCTC -3' & \\
\hline \multirow[t]{2}{*}{ IL-12 p40 } & 5'- ATGCACCTTCAGCAGCTTGGTTG -3' & 975 bp \\
\hline & 5'- CTAATTGCAGGACACAGATGC -3' & \\
\hline \multirow[t]{2}{*}{ IFN- $\gamma$} & 5'- ATGAGTTATACAACTTATTTCTTAG -3' & $501 \mathrm{bp}$ \\
\hline & 5'- TTATTTTGATGCTCTCTGGCC -3' & \\
\hline \multirow[t]{2}{*}{ Cyclophilin A } & 5'- ATGGTTAACCCCACCGTCTTC -3' & $376 \mathrm{bp}$ \\
\hline & 5'- GTTTGCCATCCAACCACTCAG -3' & \\
\hline
\end{tabular}




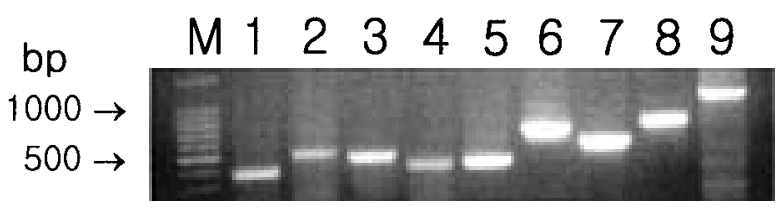

Fig. 1. Specificity of PCR. Genes of cytokine and cyclophilin A were amplified by PCR with cDNA synthesized from mRNA of PHA-stimulated PBMC for $4 \mathrm{hr}$. M, DNA marker; Lane 1, cyclophilin A (376bp); Lane 2, IFN- $\gamma$ (501 bp); Lane 3, IL-2 (465 bp); Lane 4, IL-4 (402 bp) ; Lane 5, IL-5 (405 bp); Lane 6, IL-6 (639 bp); Lane 7, IL-10 (528 bp); Lane 8, IL-12 p35 (669 bp); Lane 9, IL-12 p40 (975 bp)

\section{D-glucosamine}

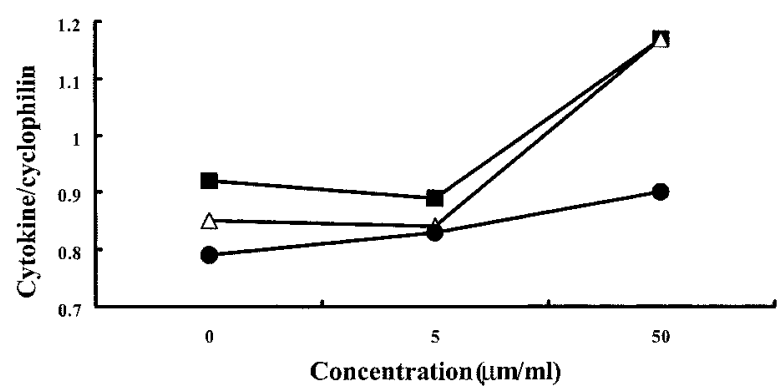

Fig. 2. Expression of cytokines in spleen cells stimulated with Dglucosamine. Expression of cytokines, such as IL-2 (closed squares), IFN- $\gamma$ (opened triangles), and IL-12 p40 (closed circles) in the spleen cells stimulated with D-glucosamine. Freshly acquired porcine spleen cells were divided into three groups. Each group was incubated for $24 \mathrm{hr}$ at $37^{\circ} \mathrm{C}$ in a $5 \%$ $\mathrm{CO}_{2}$ incubator. The spleen cells were harvested, and singlestranded cDNA was synthesized. First group, untreated control cells; Second group, $5 \mu \mathrm{g} / \mathrm{m} l$ D-glucosamine-treated spleen cells; Third group, $50 \mu \mathrm{g} / \mathrm{m} l \mathrm{D}$-glucosamine-treated spleen cells.

cells treated with D-glucosamine (data not shown).

Expression level of IFN- $\gamma$ was increased in porcine spleen cells treated with $0.005 \%$ chitosan, while IL-2 expression was increased in cells treated with 0.001 and $0.005 \%$ chitosan (Fig. 3). However, the overall expression level of IL-2 was lower than that of IFN- $\gamma$. Other cytokines, such as IL4, IL-5, IL-6, IL-10, IL-12 p35, and the IL-12 p40 subunit, were not expressed in cells treated with chitosan (data not shown).

This study demonstrates the increased expression of cytokine mRNA in porcine spleen cells treated with chitosan and D-glucosamine. Spleen cells were stimulated with chitosan and D-glucosamine for $24 \mathrm{hr}$, which was determined to be the optimal time by preliminary study. In total RNA isolation, chitosan aggregated the mRNA more than D-glucosamine, possibly due to the positive polarity of chitosan at the deacetylated site inducing the aggregation of the
Chitosan

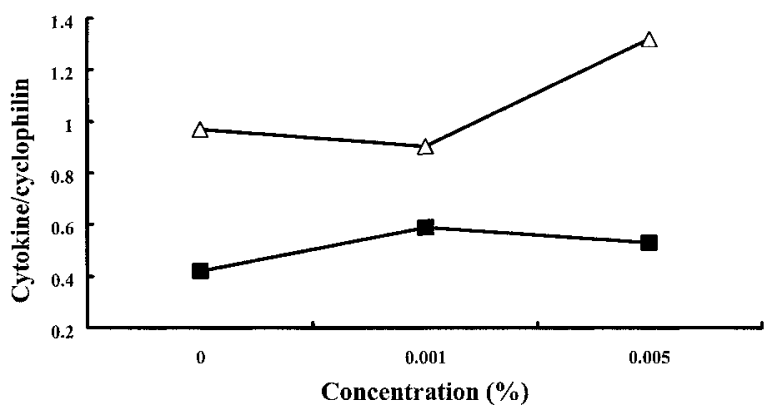

Fig 3. Expression of cytokines in spleen cells stimulated with chitosan. The expressions IL-2 (closed squares), and IFN- $\gamma$ (opened triangles) in spleen cells stimulated with chitosan. The description of experimental methods is the same as described in Fig 1. First group, untreated control cells; Second group, $0.001 \%$ chitosan-treated spleen cells; Third group, $0.005 \%$ chitosan-treated spleen cells.

negative-charged mRNA [1].

Genes of IL-2, IL-12 p40 subunit, and IFN- $\gamma$ were expressed through the treatment of chitosan or D-glucosamine. IFN- $\gamma$ gene was commonly expressed by both treatments. The expression of IL-2 was lower than that of IFN- $\gamma$ in the chitosan-treated cells. Highest gene expressions of IL- 2 and IFN- $\gamma$ were shown at $50 \mu \mathrm{g} / \mathrm{m} l$ of D-glucosamine. It is believed that IFN- $\gamma$ is the major cytokine secreted by spleen cells treated with chitosan or D-glucosamine.

The expressed cytokines including IL- 2, IFN- $\gamma$ and the IL-12 p40 subunit belong to the Th1 subset. Th1 subsets are responsible for various cell-mediated functions including the activation of Tc cells. In particular, IL-12 p40 subunit, which is secreted by D-glucosamine-treated spleen cell, at first activates the T-cells and produces IL-2 and IFN- $\gamma$ [15]. On the other hand, IFN- $\gamma$ activates macrophages and stimulates the cells to secrete cytokines, such as IL-12. These results indicate the cytokines secreted through the chitosan treatment might induce cell-mediated immunity.

IFN- $\gamma$ gene was expressed in both spleen cells treated with chitosan and treated with D-glucosamine. However, the IFN- $\gamma$-specific band appeared more frequently in spleen cells treated with D-glucosamine than with chitosan. IL-2 gene was also expressed in both treated cells, although the tendency of expression was different. It may be assumed that the biological effect of chitosan is related to its molecular weight. Chitosan has a tendency to increase affinity to LPS through its molecular mass [4] and pentamer and heptamer chitosan units seem to have better antifungal actions than the larger units [3]. Thus, the smaller the molecular weight, the more biological effects were observed.

In summary, the porcine spleen cells treated with chitosan and D-glucosamine expressed mRNA of IL-2, IFN- $\gamma$, and IL-12 p40 subunit. IFN- $\gamma$ was secreted more efficiently, and 
D-glucosamine was more effective toward the expression of cytokine genes.

This work was supported by a grant from Agricultural Research Promotion Center (No.0999-011-1-2) and Brain Korea 21 Project, Korea.

\section{REFERENCES}

1. Andreas, B. S. 2000. Int. J. Pharm. 194: 1-13.

2. Choi, I. S., Shin, S. J. and Yoo, H. S. 2001. J. Vet. Med. Sci. 63 : 1179-1182.

3. Cuero, R. G. 1999. EXS. 87: 315-333.

4. Danydova, V.N., Yermak, I.M., Gorbach, V.I., Krasikova, I.N. and Solov'eva, T.F. 2000. Biochemistry(Mosc) 65: 1082-1090.

5. Hasegawa, M., Yagi, K., Iwakawa, S. and Hirai, M. 2001. Jpn. J. Cancer Res. 92: 459-466.

6. Inui, H., Tsujikubo, M. and Hirano, S. 1995. Biosci. Biotechnol. Biochem. 59: 2111-2114.

7. Jeong, H. J., Koo, H. N., Oh, E.Y., Chae, H. J., Kim, H. R., Suh, S. B., Kim, C. H., Cho, K. H., Park, B. R., Park, S. T., Lee, Y. M. and Kim, H. M. 2000. Int. J. Immunopharmacol. 22: 923-933.

8. Krause, T.J., Goldsmith, N.K., Ebner, S., Zananis, G.A. and McKinnon, R.D. 1998. J. Invest. Surg. 11: 105-113.

9. Minami, S., Okamoto, Y., Hamada, K., Fukumoto, Y. and Shigemasa, Y. 1998. EXS. 87: 265-277.

10. Montenegro, S. M. L., Miranda, P., Mahanty, S., Abath, F. G. C., Teixeira, K. M., Countinho, E. M., Brinkman, J., Gon- calves, I., Domingues, L. A. W., Dominingues, A. L. C., Sher, A. and Whnn, T. A. 1999. J. Infec. Dis. 179: 1502-1514.

11. Mori, T., Okumura, M., Matsuura, M., Ueno, K., Tokura, S., Okamoto, Y., Miami, S. and Fujinaga, T. 1997. Biomaterials 18: 947-951.

12. Nishimura, K., Ishiharu, C., Ukei, S., Tokura, S. and Azuma, I. 1986. Vaccine 4: 151-156.

13. Nishimura, K., Nishimura, S., Nishi, N., Tokura, S. and Azuma, I. 1984. Vaccine 2: 93-99.

14. Nishimura, K., Nishimura, S., Nishi, N., Tokura, S. and Azuma, I. 1990. Mol. Biother. 2: 115-120.

15. Peter, G. S. and Mitzi, L. M. 2001. Vaccine 19: 661-668.

16. Richard, A. G., Thomas, J. K. and Babara, A. O. 2000. pp. 303-327. Kuby Immunology, 4th ed., W.H. Freeman and Company, U.S.A.

17. Seo, W.G., Pae, H. O., Kim, N. Y., Oh, G. S., Park, I. S., Kim, Y. H., Kim, Y. M., Lee, Y. H., Jun, C. D. and Chung, H. T. 2000. Cancer Letters 159: 189-195.

18. Takashi, M., Yukiko, I., Shin, I.N., Seiichi, T., Mitsunobu, M., Masahiro, O., Tsuyoshi, K. and Toru, F. 1998. J. Biomed Mater Res. 43: 469-472.

19. Tokura, S., Tamura, H. and Azuma, I. 1999. EXS. 87: 279-292.

20. Van Der Lubben, I.M., Konings, F.A., Borchard, G., Verhoef, J.C. and Junginger, H.E. 2001. J. Drug Target. 9: 39-47.

21. Wintero, A. K., Fredholm, M. and Davies, W. 1996. Mamm. Genome. 7: 509-517.

22. Yasuyuki, U., Yoshiharu, O., Takahiro, T., Yoshihiro, S. and Saburo, M. 1998. J. Biomed Mater Res. 42: 517-522. 